Research Report No. 40/2008

\title{
Transitional Justice in a Transnational World: The Ambiguous Role of Law
}

Peer Zumbansen

Osgoode Hall Law School of York University, PZumbansen@osgoode.yorku.ca

Follow this and additional works at: http:/ / digitalcommons.osgoode.yorku.ca/clpe

\section{Recommended Citation}

Zumbansen, Peer, "Transitional Justice in a Transnational World: The Ambiguous Role of Law" (2008). Comparative Research in Law \& Political Economy. Research Paper No. 40/2008.

http://digitalcommons.osgoode.yorku.ca/clpe/209 


\section{Comparative Research in Law \& Political Economy}

CLPE RESEARCH PAPER 40/ 2008

Peer Zumbansen

Transitional J ustice in a Transnational World: The Ambiguous Role of Law

EDITORS: Peer Zumbansen (Osgoode Hall Law School, Toronto, Director, Comparative Research in Law and Political Economy, York University), John W. Cioffi (University of California at Riverside), Lindsay Krauss (Osgoode Hall Law School, Toronto, Production Editor) 

CLPE Research Paper 40/2008

Vol. 04 No. 08 (2008)

\title{
Peer Zumbansen
}

\section{Transitional Justice in a Transnational WorLd: THE Ambiguous Role of LAW}

\begin{abstract}
In situations of military, political or economic transition, the reassessment of the role of law in the transition process becomes a crucial site of a people's or a nation's negotiating the past, present and future. Allusions to a tabula rasa or an année zero after traumatic collapses of societal order, however, turn into ill-fated attempts to address the challenges of confronting the past when building the future. The law's concern with nations that struggle with transition expresses itself through hybrid concepts such as transitional or post-conflict justice, restorative justice, or reconciliation. This paper revisits these instantiations and places them in the context of an increasingly transnational discourse on transitional justice. In light of the wealth of law and non-law responses to past injustice around the world today, transitional justice emerges as a form of transnational legal pluralism, highlighting the parallels of regulatory challenges confronting transition and established regimes alike.
\end{abstract}

Keywords: Transitional Justice, Law \& Development, Law of Occupation, Transnational Law, Memory

JEL classification: K23, K30, K33, K40

Author Contact:

Peer Zumbansen

Osgoode Hall Law School, York University

4700 Keele St, Toronto Ontario, M3J 1P3

Email: pzumbasen@osgoode.yorku.ca 


\title{
Transitional JUSTICE IN A TRANSNATIONAL WORLD: THE AMBIGUOUS ROLE OF LAW
}

\author{
Peer Zumbansen ${ }^{*}$
}

\section{INTRODUCTION}

This paper originates in part out of diverse legal theoretical enterprises that have, under the labels of legal realism, reflexive law, and legal pluralism, contributed to a powerful critique of traditional understandings of law and have, as such, shaped contemporary legal consciousness. In addition, this paper takes its cues from the evolving field of transitional justice, which comprises a diverse set of elements including criminal law, law \& development, the law of occupation and transnational human rights litigation. At the intersection of these two, domestically and transnationally spirited sets of legal theoretical inquiries, we find a new understanding of 'law in action'. No longer merely the label that points to the - disillusioning or uplifting - 'reality' of law as compared to the 'law on the books', but a far-reaching interpenetration of law and non-law. Transitional justice can be seen as the sobering moment at which law reflects on what it can do, what it is, and what it means. As such transitional justice emerges as a somewhat unexpected site where conflicting social rationalities test the limits of law in bringing about order, guaranteeing peace and sustaining integrity. The transnational evidence of reflections on the place of law in addressing past-injustice on the one hand and on law's part in the re-creation of a sustainable social and political order for the future on the other, is overwhelming. Ranging

\footnotetext{
* Canada Research Chair in the Transnational and Comparative Law of Corporate Governance, Osgoode Hall Law School, York University, Toronto, Canada. Email: PZumbansen@osgoode.yorku.ca. Thanks to Scott Veitch and Emilios Christodoulidis for helpful comments on this essay and their invitation to the Glasgow Workshop. An earlier version of this essay, entitled "Transnational Law and Societal Memory" was published in Veitch ed., Law and the Politics of Reconciliation (2007). This paper is part of a larger research project on the intersection of law \& development and transitional justice. See Peer Zumbansen / Ruth Buchanan eds., Law in Transition. Rights, Development and Restorative Justice. An Osgoode Reader (forthcoming, 2009).
} 
from a fast-growing body of specialized scholarship through Symposia, Journals on to Dedicated Research Centres, transitional justice has become a focus area of contemporary legal theory and concern.

What becomes apparent in this context is a distinct field of 'transnational transitional justice', an approach to understanding law, states and societies in transition that allows for a broader and deeper appreciation of the different trajectories along which regulatory forms evolve. This transnational perspective has for some time now begun to powerfully inform work in various areas of law and other social sciences, including comparative history. Building on work in post-colonial studies, comparative historiography, transfer studies and 'connected' or 'shared' histories, the programs developed under the heading of transnational history $^{1}$ and histoire croisée ${ }^{2}$ are informed by the same deeper-running transformations that have increasingly been plaguing the law in the different constellations described above. Globalization and culture are, across the board, recognized as the two deconstructivist forces that tear down the edifices of territorially defined political spaces. In law, these challenges bring about the structural and normative exhaustion of the welfare state $^{3}$ with uncertain outcome for any third-way programs or reconsolidation ${ }^{4}$, in history they demand the reconsideration of national histories, of old trajectories now revisited from the perspective of the

${ }^{1}$ See Jürgen Osterhammel, Transnationale Gesellschaftsgeschichte: Erweiterung oder Alternative?, 27 GESCHICHTE UND GESELLSCHAFT (2001); Sebastian Conrad/Jürgen Osterhammel (Ed.), DAS KAISERREICH TRANSNATIONAL. DEUTSCHLAND IN DER WELT 1871 - 1914, 2004; for critical reflections on this approach, see Hans-Ulrich Wehler, Transnationale Geschichte - der neue Königsweg historischer Forschung?, in: Transnationale Geschichte. Themen, TendenZen, TheOrien 161 (Budde/Conrad/Janz Ed. 2006).

${ }^{2}$ Michael Werner/Bénédicte Zimmermann, Beyond comparison: Histoire croisée and the challenge of reflexivity, 45 HISTORY AND THEORY 30 (2006)

3 Jürgen Habermas, The New Obscurity: The Crisis of the Welfare State and the Exhaustion of Utopian Energies [1985], in: THE New Conservatism. Cultural CRITICISM AND THE Historians' Debate [ed. and transl. by Shierry Weber Nicholsen] 48 (Habermas Ed. 1989)

4 Anthony Giddens/Patrick Diamond/Roger Liddle (Ed.), GlOBAL EuROPE, Social Europe, 2007; see already the concise analysis by Paul Pierson, The New Politics of the Welfare State, 48 WORLD POLITICS 143 (1996) 
transnational phenomena that might have shaped them. ${ }^{5}$ As formulated by Michael Geyer, "Transnational historiography [...] posits the interstices between nations, the quintessential "in-side," and the world of crossborder traffic, the quintessential "outside," as the crucial disjuncture of modern times and, hence, considers it to be the main source of change. No nation generates modern life from within, although all of them instantly historicize and, that is, nationalize modernization (to the ridiculous, but telling point that all modern inventions are ascribed to indigenous origins). The long and the short of this is that the development of nations is predicated on transnational interaction.” To the degree that this approach does not simply add 'another' history to the already existing and studied ones, it aims, much more ambitiously, to present a different national history. ${ }^{6}$

As we try to make sense of changes 'at home', these changes attain a different meaning when seen in relation to larger processes and transformations that can better be ascertained as transnational in nature. Asking painful questions then becomes unavoidable: "[...] the bottom line of an "entangled history" is that "forces and movements" beyond the control of nations interlace the seemingly autonomous unit of the nation, define or deny opportunities and options, and create material and cultural incentives for locals to act. [...]."7 As this debate among historians about the merits of a new approach to studying old histories and the solidity of the transnational history framework continues to unfold, it suggests that attempts among other expert groups, lawyers, sociologists, cultural

5 Jürgen Osterhammel/Niels P. Petersson, Globalization: A Short History (2004); Sebastian Conrad/Jürgen Osterhammel (Ed.), Das Kaiserreich transnational. Deutschland in der Welt 1871 - 1914, 2004; see also the review by Michael Geyer of the edited volume, Transnationale Geschichte, supra note 145, available at: http://hsozkult.geschichte.hu-berlin.de/rezensionen/type=revsymp\&id=812

${ }^{6}$ Geyer, loc. cit.

7 In this context, see for example, Valerie Hébert, The Politics of Punishment: War Criminals and the Struggle for German Reintegration with the West, 1948-1958, in: AfTER FAscism: PolitiCAL CULTURE AND DEMOCRATIZATION IN EUROPE SINCE 1945 (Maria Mesner \& Matt Berg eds., 2008), forthcoming; see the excellent account of the socio-political discursive climate during Adenauer's reign by NORBERT FREI, AdENAUER's GERMANY AND THE NAZI PAST (2002, with Joel Golb, orig. published in German 1996) 
theorists, exploring the intersections between law \& development, restorative justice, and the rule of law can, if at all, bear productive insights only when and where we accept this overlapping of conceptual and disciplinary perspectives as a starting point.

The following observations are made in this light. They pertain to the complexity of an emerging conceptual framework that for the time being sits strangely within a legal order built on distinctions between the national and the international. Transitional justice, against this background, can be taken as an invitation to reflect on the dynamic tensions that both uphold and constantly question such demarcation lines.

\section{NEW BEGINNINGS}

The "big bang" of military or political revolution that accompanies the setting free of powerful dynamics of transition and transformation, of postconflict, post-apartheid and post-war justice, has triggered a widespread and wide-ranging research agenda around the world that is concerned with the chances of a new "beginning" and the need to adequately account for legacies and past experiences in the process. ${ }^{8}$ From post-apartheid South Africa $^{9}$, the East- and West-German narratives of the Nazi past ${ }^{10}$ and Germany's Reunification $^{11}$, on to post-genocide Rwanda $^{12}$ and the

\footnotetext{
${ }^{8}$ Teitel, Transitional Justice (Oxford/New York, Oxford University Press, 2000); Teitel, “The Law and Politics of Contemporary Transitional Justice”, (2005) 38 Cornell Int'l L. Rev. 837-862; see the contributions in Christodoulidis/Veitch eds., Lethe's Law: Law and Ethics in Reconciliation (Oxford, UK/Portland, OR; Hart Publishing, 2001).

${ }^{9}$ Gross, "Reconciliation in South Africa" (2004) 40 Stanf. J. Int'l L. 40-107.

${ }^{10}$ Herbert/Goehler, Zweierlei Bewältigung. Vier Beiträge über den Umgang mit der nationalsozialistischen Vergangenheit in den beiden deutschen Staaten (Hamburg, Edition, 1992).

${ }^{11}$ See only Markovits, "Selective Memory: How the Law Affects What We Remember and Forget from the Past: The Case of East Germany" (2001) 35 Law and Society Review 513-563

${ }^{12}$ Mgbako, "Ingando Solidarity Camps: Reconciliation and Political Indoctrination in Post-Genocide Rwanda" (2005) 18 Harvard Human Rights Journal 201-224; Agbakwa, "Genocidal Politics and Racialization of Intervention: From Rwanda to Darfur and
} 
'transformative occupation'13 of Iraq $^{14}$, the existing accounts of this process challenge our understanding of how to go about the future while minding the past. In a crucial way, such fragile and vulnerable societal projects challenge the role of law as we learn to recognize its distinct role in ascertaining past deeds committed, plights suffered and answers found to the often unspeakable events of the past. Importantly, coupled with this reconstructive, dialogical dimension of the law's addressing of the (its) past, we find its institutional dimension. ${ }^{15}$ While the former encompasses accountability, reconstruction and 'truth', the latter relates to the recreation or foundation of democratic institutions, constitutions and the rule of law. ${ }^{16}$ But it is this tension between the allegedly extraordinary status of the events on the one hand, and the regular and reliable workings of the legal order on the other that informs and structures our approach to bringing the law to bear upon these challenges. Is law quiet in states of exceptions $^{17}$, during les heures zero, and at notorious, 'new beginnings'

Beyond" (2005) 6 German Law Journal 513-531, at
http://www.germanlawjournal.com/pdf/Vol06No02/PDF_Vol_06_No_02_513-

531_Developments_Agbakwa.pdf.

${ }^{13}$ Bhuta, "The Antinomies of Transformative Occupation" (2005) 16 European Journal of International Law [EJIL] 721-740

${ }^{14}$ Anderson, The Fall of Bhagdad (2004); Nuri Frame, “One Step Forward, Two Steps Back? The Failings of the Iraqi Special Tribunal”, Paper written for the GLOBALIZATION AND THE LAw Course at Osgoode Hall Law School, Toronto, April 2005 (on file with author).

${ }^{15}$ Chesterman, You, The People. The United Nations, Transitional Administration, and State-Building (Oxford/New York, Oxford University Press, 2004), at 154: "One of the most important and difficult challenges confronting a post-conflict society is the reestablishment of faith in the institutions of the state. Respect for the rule of law in particular, implying subjugation to consistent and transparent principles under state institutions exercising a monopoly on the legitimate use of force, may face special obstacles.”

${ }^{16}$ For an excellent overview of the panoply, see Teitel, Transitional Justice (Oxford/New York, Oxford University Press, 2000); see also Chesterman, You, The People. The United Nations, Transitional Administration, and State-Building (Oxford/New York, Oxford University Press, 2004).

17 This goes back to Cicero's oratio pro annio milone, where he states: inter arma silent leges. This has found a great renaissance in the wide-spread curtailment of civil rights in the international and domestic war on terror. Hereto, e.g., Morgan, "Slaughterhouse Six: Updating the Law of War" (2004) 5 German Law Journal 525-544; Scheppele, "Law in a 
that suggest their apartness from the otherwise silent or violent workings of the law ${ }^{18}$ New beginnings offer themselves as chances of coinciding legality and legitimacy, but the law of new beginnings is in fact tainted and burdened by the past experiences of law that question the acceptable meaning and substance of the term itself. ${ }^{19}$ "What is deemed just is contingent and informed by prior injustice.”20

This paper wishes to bring to contemporary discussions of post-conflict justice and nation-building a uniquely focused perspective. Its basis lies in an understanding of the challenges faced by law in different post-conflict contexts where law is expected to provide the grounding and starting point for national and societal reconstruction. While the distinct experiences that we can observe are deeply embedded in particular histories and trajectories of countries and peoples, the law's response has, at least since the Nuremberg trials, taken on a wider perspective. Far from suggesting a one-size-fits-all answer to the legal void after periods of atrocities and human suffering, we can observe the emergence of a transnational law of post-conflict justice. It develops from the increasingly shared experiences in designing a legal answer in situations of post-conflict reconstruction. These situations illustrate the utmost challenge of legally addressing the downfall of law, of reliability, and legitimacy. Whether law can at all adequately address the absence of (a higher sense of) law ex post, remains

Time of Emergency: States of Exception and the Temptations of 9/11" (2004) 6 University of Pennsylvania Journal of Constitutional Law 1001-1083; Oliver Lepsius, "The Relationship Between Security and Civil Liberties in the Federal Republic of Germany after September 11”, in Paul Gewirtz/Jacob Katz Cogan (eds.), Global Constitutionalism: Privacy, Proportionality, Terrorism and Civil Liberties (New Haven, Yale University Press, 2002), III 7. For its legacies, see only Schmitt, Political Theology: Four Chapters on the concept of sovereignty [1922] (transl. George Schwab) (Cambridge, MA, The MIT Press, 1986); Koskenniemi, "'The Lady Doth Protest Too Much'. Kosovo, and the Turn to Ethics in International Law" (2002) 65 Modern Law Review 159-175.

${ }^{18}$ Hay, "Time, Inequality, and Law's Violence", in Sarat/Kearns (ed) Law's Violence (Ann Arbor, University of Michigan Press, 1992), 141-173.

19 Gustav Radbruch, “Gesetzliches Unrecht und übergesetzliches Recht”, in (1946) Süddeutsche Juristenzeitung 105; see hereto the debate between Hart, "Positivism and the Separation of Law and Morals" (1958) 71 Harv. L. Rev. 593-628, and Fuller, "Fidelity to Law - A Reply to Professor Hart" (1958) 71 Harv. L. Rev. 630-672.

${ }^{20}$ Teitel, Transitional Justice (Oxford/New York, Oxford University Press, 2000), 6. 
a fundamental conundrum no different from the question of how to adequately speak of the unspeakable. ${ }^{21}$ Worldwide experiences with village courts, truth commissions and international and domestic criminal tribunals testify to a border transcending inquiry into the intricacies of transitional justice. Such experiences are being portrayed, researched, communicated and compared, and they inform contemporary and future efforts. The boundaries between legal process and alternative or complementing forms of societal reconciliation have been shown to become increasingly porous in light of the overwhelming challenge to those engaged in transformative politics. It is against this background that the distinctive role of law warrants closer inspection.

The following section of this paper will introduce the notion of transnational law [TL]. The subsequent parts will mobilize the concept and idea of transnational law to further explore the particular qualities of law's capacity to address past injustice. The transnational perspective illuminates the impasses and blind spots that straight-forward legal approaches to righting past wrongs have in common. While a growing number of examples litigating for the compensation of historic crimes have become available over the past years ${ }^{22}$, truth commissions in postapartheid South-Africa or the Gacaca Courts in post-genocide Rwanda have been taken as powerful examples for alternative, or not exclusively law-based, routes to societal reconciliation. The development of

\footnotetext{
${ }^{21}$ See, for example, Hunt, This Was Not Our War. Bosnian Women Reclaiming the Peace (Durham \& London, Duke University Press, 2004); Uwe Timm, Am Beispiel meines Bruders (Frankfurt, Suhrkamp, 2003), 91: “Die formelhafte Zusammenfassung der Eltern für das Geschehen war der Schicksalsschlag, ein Schicksal, worauf man persönlich keinen Einfluss hatte nehmen können. Den Jungen verloren und das Heim, das war einer der Sätze, mit denen man sich dem Nachdenken über die Gründe entzog. Man glaubte mit diesem Leid seinen Teil an der allgemeinen Sühne geleistet zu haben. Fürchterlich war eben alles, schon weil man selbst Opfer geworden war, Opfer eines unerklärlichen kollektiven Schicksals. Es waren dämonische Kräfte, die entweder außerhalb der Geschichte walteten ode Teil der menschlichen Natur waren, auf jeden Fall waren sie katastrophisch und unabwendbar. Entscheidungen, in die man sich nur schicken konnte. Und man fühlte sich vom Schicksal ungerecht behandelt.”

22 Baumgartner, "Human Rights and Civil Litigation in United States Courts: The Holocaust-Era Cases" (2002) 80 Wash. U. L. Quarterly 835-854; Sarkin, "Reparation for Past Wrongs: Using Domestic Courts Around the World, Especially the United States, to Pursue Human Rights Claims" (2004) 32 Int. J. of Legal Information 426-460.
} 
alternatives proved to mature fast, and contemporary assessments reveal an increasingly refined focus of inquiry into the structure of mass crimes. ${ }^{23}$ This refinement brings into play again the intricate relationship between legal process and other societal communications in post-conflict situations. The transnational law of post-conflict justice, then, unfolds less as a firmly established or contained body of law, but as an approach to structuring, with the help of legal norms and legal theory, processes of establishing accountability and legal responsibility. While contemporary acts of public remembrance might be accompanied with solemn declarations of 'historical', 'moral', or 'political' responsibility ${ }^{24}$, legal responsibility seems much harder to attain. The definitive nature of legal responsibility seems to stand in stark contrast to the truth-finding efforts that are illustrated by the examples of South-Africa or Rwanda. With victims or their heirs ardently seeking their 'day in court', often many decades after the deed $^{25}$, we are confronted with the challenge of designing the legal process in a manner that makes the practice of the law as it was known then visible and comprehensive while opening all possible ways of reconciliation today. The obstacles we face in the struggle for truth, for a better understanding and, ultimately, for forgiveness and forgetting ${ }^{26}$ must seem insurmountable in light of the arbitrary ways by which the rulers are separated from the ruled, the oppressors from the oppressed. ${ }^{27}$ "Because why should one assume that the end result of our accounting of the past

${ }^{23}$ See, for example, Eltringham, Accounting for Horror: Post-Genocide Debates in Rwanda (London, Pluto Press, 2004).

${ }^{24}$ See, for example, the preamble to the Law establishing the compensation fund "Remembrance, Responsibility and the Future", available at http://www.compensationfor-forced-labour.org/pdf/Foundation_law_consolidated_E.pdf

${ }^{25}$ See hereto, for example, Neuborne, "Preliminary Reflections on Aspects of HolocaustEra Litigation in American Courts" (2002) 80 Washington University Law Quarterly 795-834.

${ }^{26}$ See on the eminent role of forgetting, Margalit, The Ethics of Memory (Cambridge, MA/London, UK, Harvard University Press, 2002), Chapter 6: "Forgiving and Forgetting".

27 See hereto also the intriguing novel by Vladimir Nabokov, Bend Sinister (1947), republished by Vintage, 1990. I am indebted to my friend, Achim Podak, who guided me to this book. 
will move us any closer to a shared community rather than a break-down of community?"28

It is here, however, where the eminent role of the law shines through, both with regard to its contribution to the preceding, unjust legal state as well as to its current role in shaping the communicative processes that unfold between the perpetrators and the victims during transition. ${ }^{29}$ In these highly contested moments of human conflict, the role of the law is itself questionable. Against this challenge, it shall be argued that the law plays a pivotal role in the process of societal post-conflict resolution. It does so by providing for rules and for language that contain and capture otherwise dispersed understandings and value assessments as they once were expressed through a norm, a ruling or legal terminology. While law can only observe the dichotomy between legal and illegal ${ }^{30}$, this reductionism is in fact able to capture the tensions that mark conflict communication in highly heterarchical societies. Post-conflict societies are of a dramatically fragile nature, and law assumes an organizing, reminding and guiding role in providing part of the communication structure of that society. As law is being put to an existential test in post-conflict situations, the very nature of law becomes questionable. It is in this light, then, that the inquiry into the law of post-conflict justice links ongoing searches of the role of law in society in different, yet comparable contexts. It is here where the idea of transnational law begins to unfold.

${ }^{28}$ Christodoulidis, "Law's Immemorial", in Christodoulidis/Veitch (ed) Lethe's Law. Justice, Law and Ethics in Reconciliation (Oxford, UK/Portland, OR, Hart Publishing, 2001), 207-227, at 221.

${ }^{29}$ See the novel by Achmat Dangor, Bitter Fruit (New York, Grove Atlantic, 2004), for a forceful illustration of the destructive impact of apartheid rule and human failings on humans even long after the fall of the oppressor regime.

${ }^{30}$ Luhmann, Law as a Social System (K.Ziegert transl., F.Kastner, D.Schiff, R.Nobles, R.Ziegert eds.) (Oxford/New York, Oxford University Press, 2004). 


\section{The Meaning Of Transnational LaW}

The first usage of the term transnational law [TL] continues to be disputed. While scholarship focused on the origins of the term for a long time, it has since become apparent that the real challenge of TL lies in its scope and conceptual aspiration. ${ }^{31}$ Within an interdisciplinary research agenda concerning the transformation of globalized law, TL offers itself as a supplementing and challenging category. Famously conceptualized in a series of lectures by Philip Jessup at Yale Law School in $1956^{32}$, TL 'breaks the frames' (Teubner) of traditional thinking about interstate relationships by pointing to the myriad forms of border-crossing relations among state and non-state actors.

Jessup writes that he "shall use the term 'transnational law' to include all law which regulates actions or events that transcend national frontiers. Both public and private international law are included, as are other rules which do not wholly fit into such standard categories” (Jessup 1956: 2). When examining the inescapable 'problem' of people worldwide whose lives are 'affected by rules', Jessup points to the striking contingency by "which we attribute the label of 'law' to rules, norms or customs that govern various situations. It is the hallmark of TL to identify the hidden agendas and the blind spots of traditional regulatory law understandings. These are marked by clear assignments of law making authority to certain institutions on the one hand and a clear view of which norms of societal guidance are to be recognized as legal rules. In contrast, TL suggests a widening of the law making agenda and of our understanding of law as such. TL emerges from the increasingly interlocking spheres of societal norm production by public, official and private, in-official norm-setting agencies and actors.

\footnotetext{
31 Jessup, Transnational Law (New Haven, Yale University Press, 1956); Koh, "Transnational Legal Process" (1996) 75 Nebraska Law Review 181-206.

32 Jessup, Transnational Law (New Haven, Yale University Press, 1956).
} 
Based on such an expanded understanding of law, TL has begun to reach deep into the heart of contemporary struggles over the role of law within dispersed and fragmented spaces and places of norm-production. ${ }^{33} \mathrm{TL}$ reminds us of the very fragility and unattainedness of law. At the beginning of the $21^{\text {st }}$ Century, we are still at a loss to identify a theory of law that would be subtle enough not to stifle emerging identities in a postcolonial era ${ }^{34}$ while providing forms, fora and processes ${ }^{35}$ for the collision of discourses that mark post-metaphysical, legal thinking. ${ }^{36}$ TL is characterized by the emergence of norms that are no longer only generated by officially recognized sources of the law, but by a multitude of domestic, foreign and transnational norm-producers. This soft law constitutes a radical challenge to the state-based concept of law making that began to emerge in the $19^{\text {th }}$ Century and that Max Weber, among others $^{37}$, so powerfully captured as the rise of 'modern law' ${ }^{38}$ In contrast to law originating in an official constitutional order, soft law encompasses norms that are not attributable to an official author of statutory norms, and which do not appear directly enforceable by recognized, traditional means for the execution and application of legal rules. Instead, the soft law that is now emerging in many fields of regulatory law ${ }^{39}$ can be read as reactions

${ }^{33}$ For the background of the distinction between spaces and places, see Sassen, Globalization and Its Discontents. Essays on the New Mobility of People and Money (New York, The New Press, 1998).

${ }^{34}$ See, for example, Lyon, "Discourse in Development: A Post-Colonial Theory 'Agenda' for the UN Committee on Economic, Social and Cultural Rights" (2003) 10 Journal of Gender, Social Policy \& the Law http://ssrn.com/abstract=449301.

${ }^{35}$ Wiethölter, "Materialization and Proceduralization in Modern Law", in Teubner (ed) Dilemmas of Law in the Welfare State (Berlin/New York, Walter de Gruyter, 1986), 221249.

${ }^{36}$ Habermas, "Paradigms of Law" (1996) 17 Cardozo Law Review 771-784; Habermas, Between Facts and Norms [transl. William Rehg] (Cambridge, MIT Press, 1996).

${ }^{37}$ Ehrlich, Fundamental Principles of the Sociology of Law [1936] (transl. Walter Moll, introd. Roscoe Pound) (New York, Russell \& Russell Inc., 1962).

${ }^{38}$ Max Weber, Economy and Society: Part 2: Sociology of Law (1914), § 8: The formal qualities of modern law.

${ }^{39}$ See, e.g., Linda Senden, Soft Law in European Community Law, (Oxford, UK/Portland, OR, Hart Publishing, 2004); Blanpain/Colucci, The Globalization of Labour Standards. The Soft Law Track (The Hague, Kluwer Law International, 2004); Kirton/Trebilcock 
against incapacities on the side of the state to proceed with adequate legislation. The proliferation of soft law thus offers examples of what anthropologists and legal sociologists have for a long time been describing as 'legal pluralism' ${ }^{40}$ It consists of expert standards, best practices, recommendations as well as principles and standards that can be seen as fertilizing ongoing searches for 'better law' without due regard to political or geographical borders.

The relevance of TL to an understanding of contemporary regulatory challenges, however, is not restricted to the field of law as such. With regard to law, TL works itself like a drill through the few remaining security blankets hastily thrown over an impoverished and internally decaying conceptual body. But, beyond the study and practice of law, TL can serve to illuminate current searches in regulatory theory and societal self-regulation.

\section{TRANSNATIONAL LAW AND TRANSITIONAL JUSTICE}

In the context of and in concert with other complementing disciplines, TL is distinctly able to fertilize other conceptual searches while being

(Ed.), Hard Choices, Soft Law. Voluntary Standards in Global Trade, Environment and Social Governance (Aldershot, Ashgate, 2004); Trubek/Trubek, "Hard and Soft Law in the Construction of Social Europe: the Role of the Open Method of Coordination" (2005) 11 European Law Journal 343-364; Zumbansen, "The Parallel Worlds of Corporate Governance and Labor Law" (2005) 13 Indiana Journal of Global Studies forthcoming.

${ }^{40}$ Moore, "Law and Social Change: the semi-autonomous field as an appropriate subject of study" (1973) 7 Law and Society Review 719-746; Griffiths, "What is Legal Pluralism?" (1986) 24 Journal of Legal Pluralism and Unofficial Law 1-55; Arthurs, Without the Law: Administrative Justice and Legal Pluralism in Nineteenth Century England (Toronto, University of Toronto Press, 1988), 50-88 (describing the persistence of legal pluralism in light of the ever stronger tendencies to centralize law through statutory law and official courts). For further assessments of legal pluralism, see Teubner, "'Global Bukowina': Legal Pluralism in the World Society", in Teubner (ed) Global Law Without A State (Dartmouth, Aldershot, 1997), 3-28, and Perez, "Normative Creativity and Global Legal Pluralism: Reflections on the Democratic Critique of Transnational Law" (2003) 10 Indiana Journal of Global Studies 25-64. 
informed by the transformations occurring within these disciplines. As much as TL has been shown to lay bare the raw and vulnerable foundations of law in all of its absurd contingency ${ }^{41}$ and utopian aspiration, while being based in social practice administered with denominational authority ${ }^{42}$, law itself reaches out to disciplines such as history, cultural studies and anthropology to tell its own story. With legal history taking form as a transnational enterprise ${ }^{43}$, it can build on and learn from the work being done by historians and cultural studies scholars. The emergence of transnational history gives overwhelming testimony of a border-crossing inquiry into the legality-legitimacy narratives of state and nation building. Formerly conceived and framed in discrete fashions, domestic/national historical narratives reveal and communicate common experiences and semantic appropriations in comparative, transnational and global perspective. $^{44}$

The Law of post-conflict justice shifts between the unattainable poles of retribution and reconciliation, between persecution and justice, between

${ }^{41}$ See the discussion of law in Jean Anouilh, Antigone (London, UK, Methuen, 2000), transl. by Barbara Trans, edited by Ted Freeman.

${ }^{42}$ Moore, "Law and Social Change: the semi-autonomous field as an appropriate subject of study" (1973) 7 Law and Society Review 719-746; Bourdieu, "The Force of Law: Toward a Sociology of the Juridical Field" (1987) 38 Hastings Law Journal 805-813; Derrida, "Force of law" (1990) 11 Cardozo Law Review 919-1045; hereto see also the Special Issue of German Law Journal, Vol. 6, No. 1 (1 January 2005), available at: http://www.germanlawjournal.com/past_issues_archive.php.

${ }^{43}$ Merry, "Anthropology, Law, and Transnational Processes" (1992) 21 Annual Review of Anthropology 357-379; Anghie, Imperialism, Sovereignty and the Making of International Law (Cambridge, Cambridge University Press, 2005); see the contributions to Geschichte-transnational, http://geschichte-transnational.clioonline.net/transnat.asp?lang=en .

44 Bright/Geyer, "World History in a Global Age" (1995) 100 American Historical Review 1034-1060; Bentley, "Cross-Cultural Interaction and Periodization in World History" (1996) 101 American Historical Review 749-770; Middell, "Kulturtransfer und Historische Komparatistik - Thesen zu ihrem Verhältnis" (2000) 10 Comparativ 7-41; Conrad/Osterhammel (Ed.), Das Kaiserreich transnational. Deutschland in der Welt 1871 - 1914 (Göttingen, 2004); Geschichte-transnational, http://geschichtetransnational.clio-online.net/transnat.asp?lang=en 
remembrance and forgetfulness. ${ }^{45}$ It is destined and cursed to do so while its very foundations are exposed in its inadequacy at every turn. "Law is caught between the past and the future, between backward-looking and forward-looking, between retrospective and prospective, between the individual and the collective." 46 Experiences with alternative routes to societal reconciliation in past years have shown how very fragile and in many ways ill-suited the legal apparatus is in the context of post-conflict reconstruction. This moment shows the co-existing poles of law, its utopia, reconciliation and forgiving on the one hand and revolution and retribution on the other. Law and the functions it serves do not exist outside of human imagination, but law is not merely the result of human action. Instead, it is through its function that we can begin to understand the unique quality of law. As developed by the German sociologist and legal theorist, Niklas Luhmann, law serves primarily to stabilize expectations. It does so by producing rules that preserve the identification of something as "legal" over time and therefore are available for an assessment at a later point in time. The time-binding quality of law is thus the basis and the core of Luhmann's legal theory. By "moving the problem to the temporal dimension [w]e can see the social meaning of law in the fact that there are social consequences if expectations can be secured as stable expectations over time."

The law of post-conflict justice can be observed to provide exactly that. It serves to establish a framework for the stabilization of societal expectations. Just which law is most adequate to guide this process remains a great challenge. The very connectedness of the assessment of past injustice with the normative architecture of a new legal order makes it evident that often, in the application of post-conflict justice, it is not merely a specific statute or practice on trial, but a whole system. Taking

45 Adler/Zumbansen, "The Forgetfulness of Noblesse: A Critique of the German Foundation Law Compensating Slave and Forced Laborers of the Third Reich" (2002) 39 Harvard Journal on Legislation [and in: Zwangsarbeit im Dritten Reich: Erinnerung und Verantwortung / NS Forced Labor: Remembrance and Responsibility 333 (P. Zumbansen ed. 2002)] 1-61.

46 Teitel, Transitional Justice (Oxford/New York, Oxford University Press, 2000), 6.

${ }^{47}$ Luhmann, Law as a Social System (K.Ziegert transl., F.Kastner, D.Schiff, R.Nobles, R.Ziegert eds.) (Oxford/New York, Oxford University Press, 2004), 143. 
this into consideration, the realm of questions to be addressed is far greater than any piece-meal approach to remedying a wrong would ever entail. ${ }^{48}$ Recent inquiries into the specific role of constitution-making and of constitutional law in the transitional process have begun to shed some light on the intricate dynamics of legal norms in post-conflict and other transitional contexts. ${ }^{49}$ But, while the creation of constitutional bodies bears the insigna of a fresh start, of new beginnings ${ }^{50}$, the big bang and bright lights of constitution making are only too likely to render us deaf and blind to the constant struggle for law's dominion in the every day workings of established legal orders. ${ }^{51}$ The particular attention received by constitutional processes in periods of transition leads to an isolation of constitutional law and constitution making from the legal order in general. By that, the legal order becomes reified as something that functions smoothly and is in no further need of critical assessment. The exposition of constitutional moments in transition periods functions to cast a shadow on the persisting legitimacy challenges that are inherent to the legal order as such. ${ }^{52}$ Constitutional beginnings, then, share a decisive characteristic

\footnotetext{
${ }^{48}$ See hereto Thomas W. Pogge, Historical Wrongs. The Two Other Domains, in Lukas Meyer ed., Justice in Time. Responding to Historical Injustice (Baden-Baden, Nomos, 2004), 117-134, highlighting the way in which "past injustice [...] can affect present moral reasons for action.” (117)

49 See Klug, Constituting Democracy: Law, Globalism, and South-Africa's Political Reconstruction (Cambridge, UK, Cambridge University Press, 2000); Walker, "The Idea of Constitutional Pluralism" (2002) 65 Modern Law Review 317-359; see in this context the intriguing, comparative analysis by Gross, "Reconciliation in South Africa" (2004) 40 Stanf. J. Int'l L. 40-107 for South-Africa and Israel and Mattias Kumm, "The Idea of Constitutional Patriotism and its Implications for the Role and Structure of European Legal History”, (2005) 6 German Law Journal 319.

50 See the careful assessment by Dupré, Importing the Law in Post-communist Transitions, The Hungarian Constitutional Court and the Right to Human Dignity (Oxford, UK/Portland, OR, Hart Publishing, 2003), hereto also Renata Uitz, in (2005) Annual of German \& European Law Vol. 2 (Miller \& Zumbansen eds., Oxford/New York, Berghahn Books, 2005), forthcoming.

${ }^{51}$ Gross, “Reconciliation in South Africa”, at 51.

52 See only Koskenniemi, "'The Lady Doth Protest Too Much'. Kosovo, and the Turn to Ethics in International Law" (2002) 65 Modern Law Review 159-175; Orford, "Muscular Humanitarianism: Reading the Narratives of Humanitarian Intervention”, (1999) 10 European Journal of International Law [EJIL] 679-711, at 689-692.
} 
with other narratives of new (legal) orders which we often find presented as creating a forum and framework for an untainted legitimacy of societal order through law. ${ }^{53}$ Eventually, the pomp and glory of constitutional talk dissociates the fragile and constantly endangered emergence of a legal order from a long-standing critique of law. It is against this background, that we ought to reflect on the role that law can play in transition periods: not isolated and put on a podium of the world's fleeting attention and excitement, but embedded in a continuing critique of the force and weakness of legal norms.

\section{REMEMBRANCE AND UTOPIA IN LAW}

The reformation and its ensuing energies as well as the subsequent bourgeois revolutions of early modernity are characterized by the emergence of the individual subject as the centre of social and political activity. Henceforth,it has been against the individual that order and its legitimacy claims are measured. To the degree in which they are found to be foul and rotten, they are doomed and will be swept away: with the dawn of modernity, man begins to order his world in time. Human history in search of direction, in the meantime unfolding possibilities of probability and prudence. ${ }^{54}$ (I'm not sure I understand this sentence) Religious prophecy is replaced by supposedly rationalist forecast, but this forecast radiates a sense of stability similar to that which before emanated from eschatologic trust in providence or the felt threat of demise. In the interaction between the state and individual, now both matured, the knoweldge of the changeability of things is foundational in the state's creation of its own legitmacy grounds. Time's horizon is no longer as open

\footnotetext{
${ }^{53}$ For a critique, see Zumbansen, "Piercing the Legal Veil: Commercial Arbitration and Transnational Law" (2002a) 8 European Law Journal 400-432; Zumbansen, "Sustaining Paradox Boundaries: Perspectives on the Internal Affairs in Domestic and International Law" (2004a) 15 European Journal of International Law [EJIL] 197-211.

${ }^{54}$ Koselleck, "Vergangene Zukunft der frühen Neuzeit (1968)" (1979) ders., Vergangene Zukunft. Zur Semantik geschichtlicher Zeiten (zuerst erschienen in Epirrhosis. Festgabe für Carl Schmitt, hrsg. v. Barion, Böckenförde, Forsthoff, Weber, Bd. 2, 549-566 17-37; Koselleck, "Begriffsgeschichte und Sozialgeschichte (1972)" (1979) in: id., Vergangene Zukunft (Frankfurt, Suhrkamp, 1979) 107-129.
} 
as it used to be. Adopting the role of interpretor and direction-setter the state defines progression into a now unknown and final, but also manageable future.This rupture, however, is not yet absolute. Eschatology remains strong in the background and the consciousness of one's time future is a strange but courageous mix of politics and prophecy. ${ }^{55}$ Within this rationalist philosophy of progress we can see rationalist future prognostics unfolding. These are in turn still dominated by an important incorporation of the past into the imagery of the future. The events that are expected within the political horizon of historical development are seen as reoccurring and reappearing events, repeating themselves instead of being grand beginnings or last ends. From this perspective, the future that is actually envisioned for the state is simultaneously present in the past, the realm of political action contemporaneously occupied as well as confined. ${ }^{56}$ Time is important, because with ever more rapid sequences of events, brought about by deliberate human action and understood as such, the "realms of experience" (Erfahrungsräume) shrink, and the experience of the present falls victim to this unforeseeability in a way that makes the present's experience of time evade into the future. ${ }^{57}$ Presence can no longer experience itself as presence but is now forced to resort to its own historio-philosophical assumption (selbstbezogene geschichtsphilosophische Einholung). Parallelly, the semantics used to describe these both opened and closed spheres of possibilities are changing as well: Utopia can no longer characterize the experience horizon of political thinking, only Revolution. ${ }^{58}$ Yet, it is felt that revolution may put an absolute end to everything. In this respect revolution is always confronted with reaction ${ }^{59}$ and, in turn, every future oriented action is of a political nature. While utopia and revolution are hence distinguishable by the absence (utopia) and presence (revolution) of

\footnotetext{
${ }^{55}$ Koselleck, 33.

${ }^{56}$ Ibid.

${ }^{57}$ Koselleck, "'Erfahrungsraum' und 'Erfahrungshorizont' - zwei historische Kategorien (1975)" (1979) in: id., Vergangene Zukunft (Suhrkamp: Frankfurt) 349-375

${ }^{58}$ Niklas Luhmann, Die Politik der Gesellschaft (Frankfurt, Suhrkamp, 2000), 208: „Die Befürworter lernen, daß Revolution ein langfristiger Prozeß ist, die Gegner sehen Revolution als Folge falscher Ideen.“

${ }^{59}$ Koselleck, Vergangene Zukunft, 34-5
} 
deliberate human action and by the belief that change can be brought about by abruptly ending traditional ways, usually under the signum of eventual responsibility, legal practicioners of post-conflict justice are operating somewhere in between the horizons of utopia and revolution.

\section{The Changing Face Of INTERNATIONAL LAW AND THE LAW OF OCCUPATION}

The transnational perspective can further illuminate the challenge to law and societal memory that we find in various post-conflict situations around the world. These situations can be seen as entering the legal imagination against the background of a dramatically enlarged and yet fragmented and incoherent human rights agenda. While the scandalization of human rights violations drives legal efforts to address wrongdoings beyond jurisdictional boundaries ${ }^{60}$, we still seem far away from a comprehensive human rights regime. However, such a legal order might not even be desired in light of the different claims connected to the expansion of human rights. And yet, it is from this ongoing search for a better law, that the transnational law of post-conflict justice takes its cue. It develops in the light of a greater global awareness of the need for a human rights agenda and enters existing legal fields that are themselves undergoing dramatic changes. ${ }^{61}$ Because it is dramitically intertwined with ongoing legal reforms in post-conflict situations, the law of occupation vividly

\footnotetext{
${ }^{60}$ Scott, "Translating Torture into Transnational Tort: Conceptual Divides in the Debate on Corporate Accountability for Human Rights Harms", in Scott (ed) Torture as Tort (Portland, OR/Oxford, Hart Publishing, 2001), 45-63; Scott/Wai, "Transnational Governance of Corporate Conduct through the Migration of Human Rights Norms: The Potential of Transnational "Private" Litigation", in Joerges/Sand/Teubner (ed) Transnational Governance and Constitutionalism (Oxford/Portland, OR, Hart Publishing, 2004), 287-319; Zumbansen, "Beyond Territoriality: The Case of Transnational Human Rights Litigation", in: ConWEB Paper 4/2005, available at: http://www.qub.ac.uk/schools/SchoolofPoliticsInternationalStudiesandPhilosophy/Resear ch/PaperSeries/ConWEBPapers/.

${ }^{61}$ Bhuta, "The Antinomies of Transformative Occupation" (2005) 16 European Journal of International Law [EJIL] 721-740.
} 
reflects the changed legal agenda.Its recent past points to a much more encompassing agenda of reconstruction and nation-building. ${ }^{62}$

The future orientated perspective of the law of occupation has transformed this body of law from one applicable to post-military situations of desirably brief occupation and focussed on peace and sanitary stability to an encompassing legal agenda aiming at administrative reconstruction and state-building. This transformation is nowhere more visible than in the current situation in Iraq. The present state of the law of occupation in Iraq finds a distinctive expression in the United Nations Security Council Resolutions 1483, 1546 and in the letter by the US' and the UK's permanent representative Security Council of 8 May 2003. ${ }^{63}$ In this letter, both leaders were explicitly outspoken with regard to the reconstructive efforts that the occupiers ought to undertake ${ }^{64}$, and it is this mandate that the Security Council Resolution adopted almost verbatim in UNSC Resolution 1483.

The transformation of the international law of occupation is closely linked to changes in public international law at large. While this in itself seems obvious, the actual impact is far less so. ${ }^{65}$ Few observers of the international legal scene today would be willing to testify to its simple state of development. Instead, international law ranges among the most contested of legal areas at this time. Its present situation, characterized by

62 See for example the remarkable, new introduction to Eyal Benvenisti, The International Law of Occupation (Oxford, UK/Princeton, NY, Princeton University Press, 2004).

$63 \mathrm{~S} / 2003 / 538$, available at http://www.globalpolicy.org/security/issues/iraq/document /2003/0608usukletter.htm

${ }^{64}$ Id.: "The United States, the United Kingdom and Coalition partners are facilitating the establishment of representative institutions of government, and providing for the responsible administration of the Iraqi financial sector, for humanitarian relief, for economic reconstruction, for the transparent operation and repair of Iraq's infrastructure and natural resources, and for the progressive transfer of administrative responsibilities to such representative institutions of government, as appropriate. Our goal is to transfer responsibility for administration to representative Iraqi authorities as early as possible.”

${ }^{65}$ See Ian Williams, "Will International Law Shape Occupation, or the Occupation Shape International Law?”, (2003) Global Policy Forum 14 May 2003, available at: http://www.globalpolicy.org/security/issues/iraq/attack/law/2003/0514shape.htm 
a self-understanding still seeking the beginnings of its current disarray ${ }^{66}$, offers much testimony of the seemingly eternal juxtaposition of international law and politics, of universalism and hegemony. But, at the same time, international law has become so much more reflexive, that its period of untiring self-questioning and self-reassuring can now safely be declared to be past. Instead, international law's contemporary soulsearching calls for for an extended exploration of the discipline's young, but troubled history with its increased meeting-points and soulmateships with inquiries such as cultural studies, international regime studies, legal theory and transnational law, literary theory and transnational history. ${ }^{67}$ At present, however, the noises of the "real"68 are louder than the suggestions of the "social". 69 Current assessments of international law still struggle with old demons of inferiority and irrelevance in the ugly face of international politics, imperialism and hegemony, but they also reach out to encompass the particular nature of international law. ${ }^{70}$ The latter we can only begin to understand when reflecting on the very nature of the international order on the one hand, and of our understanding of law and legal regulation on the other. Our assessment of the role of law in the dynamic and contested international order depends on our understanding of this order, but there is no simple causal relationship between the social reality and the legal order. Instead, our inquiries into the structure of the

${ }^{66}$ See Michael Byers, Introduction: The complexities of foundational change, in Byers/Nolte (Ed.), United States Hegemony and the Foundations of International Law (Cambridge, Cambridge University Press, 2003), 1-22.

${ }^{67}$ Koskenniemi, "International Law in Europe: Between Tradition and Renewal" (2005) 16 European Journal of International Law [EJIL] 113-124; for further references, see Zumbansen, "Transnational Law", in Smits (ed) Encyclopedia of Comparative Law Edward Elgar, 2006), forthcoming.

${ }^{68}$ Zižek, Welcome to the Desert of the Real: Five Essays on September 11 and Related Dates (New York, Verso, 2002).

${ }^{69}$ Kennedy, "Two Globalizations of Law and Legal Thought: 1850-1968" (2003) 36 Suffolk L. Rev. 631-679; Kerry Rittich, "The Future of Law and Development: Second Generation Reforms and the Incorporation of the Social”, (2004) 26 Michigan Journal of International Law 199-243.

${ }^{70}$ Krisch, "International Law in Times of Hegemony: Unequal Power and the Shaping of the International Legal Order" (2005) 16 European Journal of International Law [EJIL] 369-408. 
international order proceed in relative autonomy from the progress made in legal theory with regard to developing an international law for the global age. ${ }^{71}$ Where our understanding of law passess from first assessments of violence (Bodin, Hobbes) on to formalization (Kelsen) to realism (Llewellyn) or to downfall (Schmitt), to reassment (Kelsen, Hart, Fuller, Dworkin) on to fragmentation and dispersement (Teubner, Sousa Santos), the legal theory of international law has undergone dramatic changes, while international law itself has assumed a contested form that today differs much from earlier challenges of its weakness. At present, International Law must remember and assess the combination of realism and utopia in its foundational myths only in the context of developments in other fields of regulatory law where changing modes of norm-creation have long been questioning dearly-held beliefs in public-private distinctions of political, legitimate rule creation on the one hand and private, market-based profit seeking on the other. ${ }^{72}$

The continuing, contested nature of international law illustrates particular challenges to the law in post-conflict situations. There is no wellcontained, settled consensus on the scope and content of the international law of occupation, nor is there a ready-to-wear, normative outfit worn by the international law of post-conflict justice. Instead, the transnational dimension in which these bodies of law interact, collide and fuse with ongoing searches for better law and better norms of nation-building and societal reconciliation in different parts of the world demonstrates the degree to which a transnational law of post-conflict justice is undercutting, accompanying and complementing the public international law of occupation in distinct ways. As the nation-state alone ceases to provide the context in which legal experiments unfold, norms are emerging in a deterritorialized sphere of world society. As narratives of post-conflict situations and the role of law and alternative ordering mechanisms continue to be developed and applied, we learn much about the

${ }^{71}$ Luhmann, Law as a Social System (K.Ziegert transl., F.Kastner, D.Schiff, R.Nobles, R.Ziegert eds.) (Oxford/New York, Oxford University Press, 2004), chapter 12.

${ }^{72}$ Zumbansen, "Sustaining Paradox Boundaries: Perspectives on the Internal Affairs in Domestic and International Law" (2004a) 15 European Journal of International Law [EJIL] 197-211. 
approximation of formerly isolated and distant regulatory experiments. ${ }^{73}$ The recognizance or execution of political will in the task of reconstructing a state after a massive and encompassing change brings to the fore every foundational myth that regularly appears in the context of nation-building. But so much more is produced by that process, as the law and politics of reconstruction collide with demands for societal reconciliation and a future looking, reconstructive agenda based on independent, self-governing terms. The law of post-conflict justice collides head-on with the programs and ideologies of "law and development."74 This conflict between shock programs and carefully, implemented, reconstructive and learning modes ${ }^{75}$ seems to characterize the options available to international consultants and legal policy programmers. Which model of the state, of the market, of society will likely underlie and guide the reconstructive efforts that depend on the financial and infrastructure support by the international community?

In seeking a tentative answer to this question, we are caught between skepticsm and enthusiasm as to what conceptions of government, governance, democracy, social welfare and private autonomy will likely evolve from this inquiry. Realizing that path-dependent trajectories of capitalist markets and social welfare regimes reflect - to a certain degree comparative institutional advantages, our perception can no longer remain blind to the intricate causation chains between national reform politics and impacts of globalized markets. In light of the often repeated complaint of what globalization actually stands for and whether, for example, globalization has caused immensive stress on welfare states or whether structural changes within these states instead promoted and fueled certain globalization phenomena, we ought to take seriously the growing awareness within many international-oriented disciplines regarding the

\footnotetext{
${ }^{73}$ See, for a powerful illustration, Swanee Hunt, This Was Not Our War. Bosnian Women Reclaiming the Peace (Durham \& London, Duke University Press, 2004), Chesterman, You, The People, supra, 180-182.

${ }^{74}$ Posner, "Creating a Legal Framework for Economic Development" (1998) 13 The World Bank Research Observer 1-11, on the one hand, and Rittich, Recharacterizing Restructuring. Law, Distribution and Gender in Market Reform (The Hague, Kluwer Law International, 2002), on the other.

${ }^{75}$ Amartya Sen, Development as Freedom (1999).
} 
limits and constraints of their traditional analytical instruments. While law needs to embrace the sociological research that nourishes the phenomena of legal pluralism, experimental law making and public-private governance mixes ${ }^{76}$, we see a similiar eyeopening within the discipline political science as it moves from a state oriented international relations approach via focussing on international regimes towards increased research of ever more flexible forms of governance. Likewise we see a sudden awakening within historical research to the phenomena of "transnationalism" which to us, however, can be no less than disturbing. If, in law, we proceed onwards in the firm belief that for the purpose of reassurance we can always turn back to law's history, to its tracks of development and even to its cross roads and turning points, it is quite unsettling to have to realize that the historian herself will have had to first develop her own adequate analytical approach before being able to firmly guide us. We can recognize and should welcome this insecurity internal to private and public international law, embracing it in the context of questions that touch upon emerging forms of international governance that are quite intricately related to changes within national legal orders. For the participants on both ends of the debate, the transnationalist and the traditionalist, there is no simple home to be found yet, no ready made bed to lie in anymore. While the transnationalist will, sooner or later, be confronted with a struggle for legitimacy mirrored so pointedly in the history of our national legal and political orders, the traditionalist also can no longer draw the blinds in order to resort to old ways. The nation state and its legal order have undergone radical changes that prompt more questions than are answers avalaible. Radical changes in public administrative practice, the inescable and ever-recurring necessity of speculative policy choices and the ensuing reflexive forms of law making in a dense public-private mix, these features prompt closer inspection but they do not resemble the quiet home that some traditionalists want to return to. From this follows that both perspectives, the transnational and the traditional one, are valid and interdependent. In fact, in some sense, we can either be both or none at all.

\footnotetext{
${ }^{76}$ See the masterful study by Arthurs, Without the Law: Administrative Justice and Legal Pluralism in Nineteenth Century England (Toronto, University of Toronto Press, 1988).
} 


\title{
VII. PAST AND FUTURE
}

\author{
"Ohne gemeinsame Begriffe gibt es keine Gesellschaft, \\ vor allem keine politische Handlungseinheit. "77 \\ "Aus den Horizonten normativer und formativer \\ Wertsetzungen kommen wir nicht heraus. "78
}

At this point, it becomes very clear that any approach to 'working through the past" ${ }^{\text {,7 }}$ creates linkages between the past and the future. "We cannot ask the historians, as Ranke did, to tell us 'wie es wirklich gewesen ist'. Instead, history is a reflection on the past from the present, and we must be aware that the common identities that we forge and the narratives that we live with emerge from processes of remembering and forgetting." 80 Indeed, the deciphering of the differently shaded heritages and legacies of emerging polities - such as post-conflict, transitional societies as well as, for example, the European Union - unveils the inseparability of an assessment of the past from the design of the future. ${ }^{81}$ The law's role in this process of to and fro is crucial as it will aid in selecting, thereby illuminating as well as silencing elements of the past, and even complete

77 Koselleck, Begriffsgeschichte und Sozialgeschichte, 108 ("Without common terminology, there is not society, and above all no unity for political action”)

${ }^{78}$ J.Assmann, Das kulturelle Gedächtnis (Munich, Beck, 2nd ed., 1992) 129 ("We cannot escape the horizons of normative and formative value assessments.”)

${ }^{79}$ Adorno chose the term, Aufarbeitung der Vergangenheit, to address the problems raised by the term, Vergangenheitsbewältigung, which would be translated as 'coming to terms with the past'. See, Theodor W. Adorno, "The Meaning of Working Through the Past", in Id., Critical Models (transl. Henry W. Pickford, New York, Columbia University Press, 1998), 89.

${ }^{80}$ Christian Joerges, "Introduction to the Special Issue: Confronting Memories: European 'Bitter Memories' and the Constitutionalization Process: Constructing Europe in the Shadow of its Pasts", (2005) 6 German Law Journal, 245-254, at 250.

81 Zumbansen, "Europe's Darker Legacies? Notes on 'Mirror Reflections', the 'Constitution as Fetish' and other such Linkages between the Past and the Future" (2005) 43 Osgoode Hall Law Journal 321-334, at 331; Veitch, "Legal Right and Political Amnesia", in Nuotio (ed) Europe in Search of 'Meaning and Purpose' (Helsinki, Faculty of Law, University of Helsinki, 2004), 89-106. 
pasts. ${ }^{82}$ And, here we apparently end back where we started. Law appears as a salvaging force that can guide us out of the dark by its very appeal to legitimacy. But, that the law has never been our own, is the tragic lesson learned by the man waiting before the gates of the law as well as by all the others that wait for law's healing hand. ${ }^{83}$

${ }^{82}$ See the remarkable account of the impact of data protection and file archiving laws in Germany by Markovits, "Selective Memory: How the Law Affects What We Remember and Forget from the Past: The Case of East Germany" (2001) 35 Law and Society Review 513-563.

${ }^{83}$ See Russell Miller, Much Ado, But Nothing: California's New World War II Slave Labor Statute of Limitations and Its Place in the Increasingly Futile Effort to Obtain Compensation from American Courts, in Peer Zumbansen (ed.), NS-Forced Labor: Remembrance and Responsibility (Baden-Baden, Nomos, 2002), 201-211 (also in [20012002] 23 Whittier Law Review 121); Id., Before the Law: Military Investigations and Evidence at the Iraqi Special Tribunal (2005) 13 MSU-DCL Journal of International Law. 